\title{
Toraja Coffee As Tourism Identity: Perception Of Foreign Tourists
}

\author{
Hasyim Muhammad ${ }^{1}$, Kuswarini Prasuri², Masdiana $^{3}$ \\ \{hasyimfrance@unhas.ac.id ${ }^{1}$, p.kuswarini@fib.unhas.ac.id ${ }^{2}$, masdinov17@gmail.com ${ }^{3}$ \} \\ Hasanuddin University, Jl. Perintis Kemerdekaan KM. 10 Makassar, Indonesia ${ }^{1,2,3}$
}

\begin{abstract}
Place branding is a device in regional development to improve the competitiveness of the face of global competition. Toraja coffee is the identity of the Toraja region that has potential as a tourism icon. The main issues in this research are how to enhance the image and reputation of the Toraja coffee as a new tourism destination. Qualitative research methods are used to answer this descriptive problem formulation with a focus on the exploration of the social situation in depth, broad and thorough about coffee as the icon of Toraja tourism. Source data obtained through interviews and questionnaires with foreign tourists. The results of this study concluded that Toraja coffee is a variant of the destinations that can enhance the image of the Toraja region as world tourism.
\end{abstract}

Keywords: place branding, Toraja coffee, tourism identity, destination.

\section{Introduction}

A long history, Toraja coffee has been known since the $19^{\text {th }}$ century in Europe through Dutch Trade (VOC). Cafes in Europa have been talking about Toraja coffee (http://kopitoraja.weebly.com/info-kopi-toraja/sejarah-kopi-toraja). Based on notes written by Van Dijk, an owner of Dutch coffee plantation in Toraja who has opened coffee plantation in Rantekarua area in 1928 states that he has found old coffee trees aged about 200 to 300 years in Sa'dan. According to that literature, coffee in Toraja has been introduced by Arabian traders who conduct their activities in South Sulawesi. The business of Arabian traders in South Sulawesi, especially in Gowa port in Makassar, has been there since the 17th century.

Furthermore, B.H. Paerels, an agronomist from the Netherlands had observed coffee plantations in Toraja in 1923. It is concluded that coffee production was mostly started in 1873 and 1878, seen from the age of coffee trees that he observed. The coffee tree is introduced to Sa'dan plateau from Alla in Duri, brought by retail traders from Bugis to Mandar in the northwest (Bigalke, 2005).

Although Toraja coffee was the most-wanted product for both local and foreign traders (Dutch) at that time and has been known since the 19th century in Europe for its quality, Rambusolo culture, death ritual ceremony, becomes the characteristic of Toraja that has been introduced as world tourism. Toraja government and all tourism stakeholders in Indonesia promote tourism product of Rambusolo culture to foreigners by arranging a tour package named Toraja Tour. The Tour programs offered by almost all tour and travel are tourist sites related to Rambusolo culture, namely ethnic graves of Toraja and death ritual ceremony of Rambusolo. Toraja, with Rambusolo tradition and Tongkonan houses, has been known as 
world tourist sites. Foreign tourists, especially those from Europe, have made Toraja tourism as one of the tourist destinations after Bali and Java (Yogyakarta).

The monetary crisis that happened in Indonesia in 1998 gave bad impact on Indonesia's tourism, including tourism in Toraja. Although Toraja has been known as a world tourist site, the number of tourists has been decreasing since 1998. For example, Central Bureau of Statistics in South Sulawesi records that the number of foreign tourists visiting South Sulawesi in 2015 decreased up to $13.79 \%$ from the previous month, which is from 465 people into 263 people. The head of Central Bureau of Statistics in South Sulawesi, Nursam Salam, said that five countries most-frequently visiting Indonesia through the entry of Makassar in December are Malaysia, Singapore, United States of America, Tiongkok, and France. The number of foreign tourist from the five countries is 1.105 people or $87.49 \%$ of the total number of foreign tourists that enter through Makassar (http://makassar.radiosmartfm.com/jurnal-makassar/5309desember-2015-kunjungan-wisman-di-sulsel-menurun-signifikan.html).

Based on the research result conducted by (Hasyim et al, 2019), so far, the main tourist site for Toraja that is still maintained and promoted to foreign tourists is the culture of tradition, of which the character of the tourist site consists of graves and traditional houses. However, the result of interview and questionnaire with the respondents (42 foreign tourists, and 40 of them are French) shows that they are bored with those two kinds of the tour because there is no other alternative besides graves and Tongkonan houses. Foreign tourists' satisfaction is when they come to Rambusolo ceremony.

The result of the survey conducted by Swisscontact shows that tourists choose "nature" as the most significant attractiveness in Toraja. Death ritual ceremony mostly used to attract tourists is not the main destination that the tourists want to visit. Based on tourists' taste, they prefer the nature of Toraja such as the view of rice fields, coffee and clove plantation, and the daily life of Toraja people as farmers. Tourists coming to Toraja is not only for seeing Rambusolo, but also strolling rice fields, planting rice, tracking to the coffee plantation, harvesting coffee and clove, feeding livestock (buffalo and pig), and tasting local drink such as sweet palm wine and coffee as well as traditional foods (http://www.torajaparadise.com/2015/09/transformasi-toraja-memulihkan-amornya_15.html).

Back in the past when the monetary crisis happened in 1998, the significant impact for Toraja was the decreasing number of foreign tourists coming there. Based on the result of a survey conducted by the Regional Government of Toraja above, the government of Toraja and North Toraja have made Toraja coffee as an icon of coffee tourism. Place branding of Toraja with the tagline of "Coffee Regency" is a program for Toraja image, which has been known for its traditional culture of death ritual ceremony. The objective of the study of this research how is the perception of foreign tourists toward Toraja coffee as a tourism identity?

\section{Method}

The population of this research was foreign tourists visiting Toraja. Data of statistics showed that most of the foreign tourists coming to Toraja are from Europe (France, Germany, Italy, the Netherlands, and Spain). Data collection was conducted by visiting main tourist destinations and death ritual ceremony Rambusolo, which were frequently seen by foreign tourists. Since the foreign tourists were mostly from France, the questionnaires were written in two languages, French and English.

Data collection was conducted through the survey, informal interview, and observation in the research location during the high session of the visit in Toraja. The survey was carried out 
to verify the validity and clarity of the questionnaires. The informal interview was conducted to foreign tourists in the location of the tourist sites.

Data of the result of the questionnaire needed was the perception of tourists toward Toraja as the characteristic of coffee tourism. The question given to foreign tourists was their perception of Toraja coffee as a tourism commodity before and after visiting Toraja.

Regarding the expansion of Toraja area into two regencies, this research was conducted in two regencies, namely Tanah Toraja and North Toraja. Those regencies are tourist sites even though - based on the topography - most of the tourist sites were in North Toraja. This research was conducted from July to November 2018 in North Toraja, South Sulawesi. There are agro-tourisms designed in those regencies. The first one is natural tourism Pango-Pango, which is managed by agro-tourism and located in Tanah Toraja Regency, and the second one is a coffee plantation in Sapan, North Toraja Regency.

\section{Results and Discussion}

In the Principles of Marketing (Kotler \& Amstrong, 2012), the definition of a brand is "name, term, sign symbol (or a combination of these that identifies the maker or seller of the product." Thus, the brand is an identity of a product that differentiates a product with another product. The brand has a communication function in delivering feature, benefits, and specific service of a product consistently. Moreover, brand has four characteristics, namely: (1) attribute, signifier that is attached to a product and reminds people of the product; (2) benefits, function of a product felt by the buyer; (3) value, it is related to how a buyer value a product that he/she uses; (4) personality, it deals with character attached to a product that becomes the image of the product. A brand personality is the specific mix of human traits that may be attributed to a particular brand (Kotler \& Gary, 2012).

Besides personality, the brand also has a brand image. According to Kotler and Keller (2012), brand image "describes the extrinsic properties of the product or service, including how the brand attempts to meet customers' psychological or social needs." Brand image is a meaning constructed by consumers of a brand and a sign system in the minds of consumers. Brand image is related to brand indexicality which creates trust or confidence in the product. A product created by a brand, identity and brand identity can have a sharp image according to consumer perceptions. A strong brand image can be in the form of superiority in function, association, waking up specific experience, and others.

\begin{tabular}{|l|l|l|l|}
\hline Brand identity & \multicolumn{1}{|l|}{\begin{tabular}{|l|l|}
\hline Market positioning \\
\hline $\begin{array}{l}\text { How the identity } \\
\text { and personality of } \\
\text { the brand are } \\
\text { constructed by } \\
\text { the owners of the } \\
\text { brand }\end{array}$
\end{tabular} \mid $\begin{array}{l}\text { The process of } \\
\text { construction of } \\
\text { image or identity } \\
\text { of a product that } \\
\text { consumers are } \\
\text { feeling a certain } \\
\text { way }\end{array}$} \\
\hline
\end{tabular}

Fig. 1. Process of transforming brand identity to brand image 
The brand is not only a commercial product produced by a person or a company. It can be in the form of place (country, city, area, tourist site) that has a market target (visitors). Place, such as a tourist area that has attractive locations needs marketing or promotion or called place marketing. According to Kotler (2012), "place marketing involves activities undertaken to create, maintain, or change attitudes or behavior toward particular places. Cities, states, regions, and even entire nations compete to attract tourists, new residents, conventions, and company offices and factories".

Place marketing stated by Kotler is called place branding. Place branding, place marketing is a new terminology in marketing including nation branding, region branding, and city branding. Place branding is a communication process of creating an image of a place to the market target. In this case, place branding is an approach used to market a city or region based on its character or potential. Thus, a brand is related to the quality of a product. Place branding means how the quality or style becomes an identity of a place (city or country). Anholt (2010) gives an example that in a trademark, the success of the Italian car brand is related to the quality of Italian style, that is, speed and innovation. Perfume brands are always associated with France which has a classy brand image and lifestyle. The image of Japanese television brands emphasizes high-tech expertise. Place branding for tourism areas can be seen through the following examples: France is famous for its tourist attraction of Eiffel tower, California in the United States has a tourist attraction of Disneyland Park, while Indonesia has Bali known as a world tourism city with an iconic island of the gods.

Kotler in Yananda and Salamah (2014) divides place image into four categories, namely positive image, reduced image, negative image, mixed image, contradictory image, and attractive image (excessive image). A strong positive image on the perception of foreign tourists is Toraja has a traditional cultural image (ethnic). It is inseparable from the promotion of Toraja tourism by stakeholders (tour and travel agents) that still sell the tour package of Toraja ethnic culture (death ritual ceremony, graves, and Toraja traditional house). Meanwhile, Toraja coffee as an image and identity of Coffee Regency (tourist destination) is still a poor image for foreign tourists.

\subsection{Identity of Toraja as a Coffee Tourism}

Attributes are physical characteristics that become a brand identity and differentiate the product with other coffee brands. The Toraja coffee attribute is a Toraja Tongkonan traditional house. Toraja traditional home as a logo on the packaging is a representation of the origin of the product. In indexicality, Toraja traditional house always refers to the Toraja region and traditional culture owned by ethnic Toraja. Almost all Toraja coffee products use the iconic Tongkonan traditional house as the identity and personality of Toraja Coffee.

Benefit means how consumers feel the benefits (taste and aroma) of Toraja coffee benefit. The literal meaning of Toraja coffee is marked by Toraja coffee as a souvenir for visitors, both those outside the Toraja area like in Makassar and Toraja. Foreign and domestic tourists visiting Toraja buy Toraja coffee products as souvenirs and want to try and enjoy the quality of Toraja coffee. The motivation of the visitors to buy Toraja coffee is the image of Toraja coffee as a high-quality coffee. Toraja coffee means coffee with the best quality.

Value means the consumer's perception of the quality of Toraja coffee. Tourists' intention to visit Toraja, to enjoy Toraja coffee at cafes in Toraja, and to buy it as supplies and souvenirs show that there is value in Toraja coffee products believed by consumers. Based on the results of interviews with foreign tourists (Europeans) who enjoy Toraja coffee in cafes, they say that Toraja coffee has a distinctive aroma that is not like other coffee brands. 
Personality (brand personality), is the qualities associated with a product. The personality of Toraja coffee brand is associated with Toraja tourist destinations, the characteristics of Toraja culture (Toraja traditional houses), and the best quality of Arabica and Robusta of Toraja coffee. Toraja coffee symbolizes Toraja cultural tourism.

The result of interviews with foreign tourists about Toraja coffee shows that coffee products are always associated with Toraja cultural tourism which has been globally known and becomes one of the world's tourism. So, the personality of the Toraja coffee brand associates with Toraja traditional house as a symbol of Toraja culture.

Toraja identity as a coffee regency is an instrument that forms the basis of the branding process. The character of "Coffee Regency" allows a product (Toraja Coffee) as an image, to be different from other places. Toraja image as the Coffee Regency is very much related to the strength of the identity of Toraja coffee which is attached to Toraja as a region that produces coffee. The image of Toraja coffee is a reflection of the identity of Toraja coffee.

\subsection{Image of Toraja Coffee as a Tourist Destination}

Brand image is "the set of beliefs or associations that are named or signed in the mind of the consumer" (Anholt, 2010). Furthermore, Helin (2014) brand image is "the current view of the customers about a brand. It can be defined as a unique bundle of associations within the minds of target customers. It signifies what the brand is present stands for." Brand image is related to the perception or association is given by consumers to a product. Product trust by consumers is closely related to knowledge and experience with products.

The brand image of a place, "Toraja as a Coffee Regency" is a set of beliefs created by the region (government) and perceived by visitors (tourists) and society in general. The strength of the image of Toraja Coffee is very dependent on the identity of Toraja Coffee which is built and become a positioning for tourists.

The North Toraja Government and Toraja Regency have a program by creating a new pleasant image, that is, Toraja coffee as a regional identity, and no longer emphasizing Toraja image as a tourism area associated with graves. To develop the image of Toraja as "Coffee Regency," the superior product of Toraja coffee (Arabica and Robusta) is included in every Indonesian Special Coffee Contest (KKSI) organized by the Association of Indonesian Coffee Exporters and Industries (AEKI). This event is held every year. This contest also involves foreign judges, such as from Germany, Australia, and Japan. Each of the judges the quality of coffee without knowing where the coffee came from. They are only provided with a cup of warm coffee given a number. They will then value each number. At the end of the event, they are notified of the origin of the coffee. In the $8^{\text {th }}$ KKSI Contest in 2016, Toraja Arabica Coffee becomes the winner (1st place), and in the 2017 KKSI 9 contest, Arabica Toraja coffee is the second winner. Besides, the tour program conducted by the government of Tana Toraja is a Toraja Coffee Festival which is held every year, with segmentation of visitors of foreign and domestic tourists.

The result of the interview is explained below. Foreign tourists get the information of Toraja as a tourist destination in Indonesia through information on the internet and information obtained from relatives or families who have visited Toraja. A definite description of Toraja is obtained through word of mouth, especially those who have visited Toraja. To get more explicit and more detailed information, foreign tourists seek information through the travel agent, for example, brochures containing Toraja tour packages and information about Toraja in the form of video. What they know about Toraja is that Toraja is ethnic tourism that has a cultural tradition (uniqueness) and gives a new experience for tourists that other tourism 
areas in the world do not have. What they mostly know is new graves, death ritual ceremony with the slaughtering of sacrificial animals (buffaloes) and Tongkonan houses.

Meanwhile, the information about culinary that they know is Toraja coffee. Tourists know Toraja coffee, and those who are coffee lovers want to try and buy it as souvenirs. However, in the Toraja Tour program offered by a travel agent, none of them have agritourism programs (such as coffee plantations and enjoying Toraja coffee at tourist sites). For tourists who have got information about Toraja coffee, they try to taste Toraja coffee at cafes in Toraja outside the tour schedule, for example in the afternoon or evening.

\section{Conclusions}

The result of this research shows that Toraja Coffee is an agro-tourism that is potential to be developed in Toraja as world tourism, besides its cultural tradition that has been already popular.

Based on the perspective of foreign tourists toward Toraja tourism, the improvement of Toraja coffee as the identity of Toraja becomes an alternative of tourist site that completes the tourism of cultural tradition (graves and Tongkonan houses) as the main tourist sites. Though Toraja coffee only becomes complementary of the main tourist sites, it has the potential to develop tourism in Toraja and to become image and identity of Coffee Regency.

\section{Acknowledgments}

Thank you very much to the Government of Toraja Tana Toraja and North Toraja Regency, South Sulawesi that has helped and facilitated the activities of research on coffee as a destination for tourism. This paper was written as a result of the study on coffee tourism in the region of Toraja.

\section{References}

[1] Somov, A.: Wildfire safety with wireless sensor networks. EAI Endorsed Transactions on Ambient Systems. pp. 1-11 (2011)

[2] Motaz, A.: Start programming using Object Pascal. Vol. 2, pp. 10-11. Legally Free Computer Books, US (2013)

[3] Anholt, Simon: Definitions of place branding - Working towards a resolution. Place Branding and Public Diplomacy Vol. 6, (1), p. 1-10 (2010)

[4] Arthur : Arabika Toraja Juara Kontes Kopi Indonesia 2016. Retrieved from https://www.karebatoraja.com/arabika-toraja-juara-kontes-kopi-indonesia-2016/

[5[ Bigalke, Terance W. : Sejarah Sosial Tana Toraja (Diterjemahkan dari Tana Toraja: A Social History of an Indonesian People). Yogyakarta: Ombak. (2016)

[6] Direktorat Jenderal Kekayaan Intelektual Kementerian Hukum dan Ham RI. : Pengenalan Merek. Retrieved from http://www.dgip.go.id/pengenalan-merek (2018)

[7] Hasyim, Muhammad, Akhmar, Andi Muhammad, Wahyuddin, Prasuri, Kuswarini : Foreign Tourists' Perceptions of Toraja as a Cultural Site in South Sulawesi, Indonesia. African Journal of Hospitality, Tourism and Leisure, Vol. 8 (3), p. 1-13 (2019)

[8] Helin, Sasi : Brand image and identity Case Lumene Oy. Thesis. Finland: Arcada University of Applied Sciences (2014) 
[9] Kotler, Philip \& Gertner, David : Country as Brand, Product, and Beyond: A Place Marketing and Brand Management Perspective. Journal of Brand Management. Vol. 9(4), p. 249-261 (2002)

[10] Kotler, Philip \& Keller, Kevin Lane : Marketing Management. New Jersey: Prentice Hall (2012)

[11] Kotler, Philip \& Armstrong, Gary : Principles of Marketing. New Jersey: Pearson Prentice Hall (2012)

[12] Kotler Philip, Kertajaya Hermawan \& Setawan, Iwan : Marketing 3.0. Jakarta: Erlanga (2010)

[13] Mosco, Vincent : The Political Economy of Communication (Second Edition): London: Sage Publications Ltd. (2009)

[14] Rahadiansya, Cristian : Transformasi Toraja; Memulihkan Pamornya Sebagai Destinasi Wisata. Retrieved from https://orangtoraja.blogspot.com/2015/09/transformasi-toraja-memulihkanpamornya_15.html (2015)

[15] Rahmansyah : Selamat, Kopi Arabika Kerinci Jadi Pemenang Kontes Kopi Spesialti Indonesia ke 9 2017. Retrieved from https://www.kabarrantau.com/selamat-kopi-arabika-kerinci-jadipemenang (2017)

[16] Sejarah Kopi Toraja. Retrieved from http://kopitoraja.weebly.com/info-kopi-toraja/sejarah-kopitoraja (2017)

[17] Yananda, M. Rahmat \& Salamah, Ummi : Branding Tempat: Membangun Kota, Kabupaten dan Propinsi Berbasis Identitas. Jakarta: Makna Informasi (2014)

[18] Victoria, Agatha Olivia : Indonesia, Negara Eksportir Kopi Terbesar Dunia? Retrieved from https://www.goodnewsfromindonesia.id/2017/08/11/indonesia-negara-eksportir-kopi-terbesardunia (2017) 